\title{
Correlation between receptive vocabulary skill, syntactic awareness, and word writing
}

Vanessa Magalhães Barbosa1 https://orcid.org/0000-0002-2623-6156

Cláudia da Silva ${ }^{2}$ https://orcid.org/0000-0003-3091-8448

Universidade Federal Fluminense - UFF, Curso de Graduação em Fonoaudiologia, Nova Friburgo, Rio de Janeiro, Brasil.

2 Universidade Federal Fluminense - UFF, Departamento de Formação Específica em Fonoaudiologia, Nova Friburgo, Rio de Janeiro, Brasil.

Research carried out in the Health Institute of Nova Friburgo by the Department of Specific Training in Speech and Hearing Therapy - FEF, Federal Fluminense University - UFF - Nova Friburgo, Rio de Janeiro, Brazil.

Conflict of interests: Nonexistent

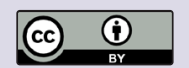

Received on: March 17, 2020

Accepted on: May 4, 2020

Corresponding address:

Cláudia da Silva

Avenida Comte Bitencourt, 158, apto. 304 CEP: 28625-000 - Nova Friburgo -

Rio de Janeiro, Brasil

E-mail: claudiasilvafono@yahoo.com.br

\section{ABSTRACT}

Purpose: to verify the correlation between receptive vocabulary, syntactic awareness, and single-word orthographic writing tests.

Methods: a total of 42 third graders from elementary public schools, of both genders, aged 8 to 9 years, participated in this study. To obtain the data, the vocabulary test through images, syntactic awareness test, word dictation test, and writing under dictation test were used. For normality distribution, the Kolmogorov-Smirnov test was used; in the relationship between the variables, the Spearman correlation test and the $\mathrm{R}^{2}$ value test were used ( $p$-value $\leq 0.05$ ).

Results: there was a statistically significant difference, with a moderate positive correlation between receptive vocabulary, syntactic awareness, and word dictation (values near 0.40 to 0.50 ); moderate-to-high, between grammatical judgment, word dictation, and writing under dictation (values near 0.50 to 0.75 ); low-to-moderate, between word dictation and grammatical correction, grammatical and ungrammatical correction, and word categorization (values near 0.25 to 0.50 ); and moderate-to-high, between word dictation and writing under dictation (values near 0.50 to 0.75 ).

Conclusion: a positive correlation was identified, ranging from low to high, pointing to the direct and favorable relationship between receptive vocabulary skills, syntactic awareness, and single-word writing.

Keywords: Learning; Handwriting; Language; Vocabulary; Educational Status 


\section{INTRODUCTION}

A channel of communication inherent to humans, oral language allows the exchange of information based on a language ${ }^{1}$. Oral language undergoes some stages until it is acquired, although it does not need to be explicitly or formally taught since the child acquires this tool from their contact with fluent speakers of the same language $\mathrm{e}^{2,3}$.

The use of multiple words in speech begins when the child has enough vocabulary and becomes capable of using without difficulties the words they have learned. The functional employment of vocabulary is related to the development of cognitive processes and associated metalinguistic skills so that the knowledge of morphology, lexicon, semantics, and syntax is improved, broadening the person's oral productions ${ }^{4,5}$.

Regarding vocabulary, it can be stated that its use depends on various factors, and is directly influenced by environmental and cognitive stimulation ${ }^{6,7}$. Hence, it is expected that children, at the very beginning of their formal education, use expressive vocabulary applied to different types of sentences, as statements and questions, and that they be apt to understand what the speaker conveys, through receptive vocabulary ${ }^{8,9}$.

Among the metalinguistic skills, syntactic awareness is the tool used to handle words and structures, based on the person's knowledge of concepts and rules that underlie the langugae ${ }^{10}$. While learning literacy, the child is introduced to the formal learning of reading and writing. Syntactic awareness is essential to such an acquisition, as the child, before reading and writing, uses oral communication to deal with their surroundings, understanding sentence structure rules related to orality - rules that later will be applied for them to learn reading and writing ${ }^{11,12}$.

Hence, while the child learns how to read, their memory of letter sequencing and word identification is formed, and the information until then present in the auditory and visual memory is coded, using syntax to give them order and coherence in the text ${ }^{13,14}$. However, various factors influence this stage, such as their social, economic, and cultural context, as well as the orthographic irregularities of the Portuguese language ${ }^{8,15}$.

Orthographic writing reflects the complex learning of language in its semantical, syntactic, and phonological aspects, counting also with the motor function, to finally express written texts. These require refined movements to properly handle, explore, and grasp the skills that will result in the production of graphic symbols ${ }^{12}$.
Handwriting is apprehended and improved throughout the schoolyears. It can be defined as the action of handling certain objects (letters) to form visual codes capable of perpetuating a message ${ }^{16}$. At the beginning of the formal learning of handwriting, some errors may happen - e.g., inverting and/or substituting letters for numbers -, since, in general, these codes are initially seen as symbols ${ }^{17}$.

As in oral language, certain stages are expected to happen in the development and acquisition of writing. These stages are divided into two phases; first, the alphabetical one, in which the child represents the letters in equivalence to the speech sounds. The second is named orthographic phase when the person can write according to the opacity of the language - i.e., writing without completely depending on the phonemic support, understanding that each letter may have multiple functions in a word ${ }^{18}$.

Since not all words in Portuguese are regular, and the graphophonemic correspondence may vary, the child needs to learn rules and concepts, dependent or not on contexts, to produce alphabetical writing ${ }^{19,20}$. Considering these concepts, the child can be said to have a previous notion of syntactic awareness originated in oral language, which is their support to apply rules acquired when learning how to write ${ }^{21}$.

Written production depends on two routes to be developed; one is through the sublexical route - i.e., through grapheme-phoneme conversion, used mainly for unfamiliar and low-frequency words, and pseudowords. The other route is the lexical one, in which the person accesses the words stored in their lexicon to write frequent, familiar, and regular words. Thus, vocabulary has a significant influence in writing, since the greater the storage and long-term memory of words, better tends to be their competence in writing ${ }^{1,5,8,9}$.

Hence, verifying the correlation between language skills (as the auditory receptive vocabulary, syntactic awareness, and single-word writing) can aid in developing intervention proposals for difficulties in learning, to solve possible obstacles identified in the foundations of learning how to write.

Given the above, this study aimed to verify the correlation between receptive vocabulary, syntactic awareness, and orthographic single-word writing tests in elementary school third graders.

\section{METHODS}

This is a quantitative, exploratory, experimental research, approved by the Research Ethics Committee 
of the Universidade Federal Fluminense, campus at Nova Friburgo, RJ, Brazil, under protocol number 2.855.396.

A total of 42 elementary school third-grade children, duly enrolled in the public-school system, aged eight to nine years, from both genders, participated in this study. The third grade was chosen because it is the time when the children have already gone through the practice of writing independently of rules and have been introduced to learning orthographic rules. Data collection took place at the end of the second semester of the school year.

The sample's inclusion criteria were the signing of the Informed Consent and Assent Form; schoolchildren with visual and auditory acuity, and cognitive performance within normality standards; schoolchildren with motor development within typical standards and who had never been submitted to neuropsychological, speech-language-hearing and/or psycho-pedagogical intervention, according to data described in their school record.

The sample's exclusion criteria were the non-signing of the Informed Consent and Assent Form; schoolchildren with an interdisciplinary diagnosis of learning disorders, attention-deficit/hyperactivity disorder (ADHD), specific language disorder (SLD), phonological deviation and/or developmental coordination disorder (DCD); schoolchildren with visual and auditory acuity, and cognitive and motor performance below normality standards; and the presence of other genetic or neurological syndromes, according to data described in the school report.

The classes submitted to assessment were selected based on the school principal's indication, so that the procedures could be applied in schedules defined by the teacher, not causing any loss to the children's learning.

All the selected schoolchildren participating in the research had the Informed Consent Form signed by their parents or guardians, in compliance with the resolution 466/12 of the National Health Council (Conselho Nacional de Sáude - CNS), before beginning the assessments. Also, before the assessments began, the children signed the Informed Assent Form, in compliance with the same resolution, CNS 466/12.

The assessment instruments used included the vocabulary test through images (TVfusp) ${ }^{22}$, whose purpose is to assess the degree of development of auditory receptive vocabulary, as well as interpret the results obtained as an indication of school aptitude and achievement.
The decision to use a receptive vocabulary test considered the research participants' schooling since the standardized national procedures available to assess expressive vocabulary are scarce for their school grade.

In its complete version, the TVfusp consists of five training sheets and 139 test sheets, ordered by an increasing level of difficulty. It is administered in groups of five children. Each item of the test has four alternatives containing images; the child is supposed to point to the image that best represents the word spoken by the assessor. In the end, the total number of right answers is calculated.

For the analysis of results obtained in this study, the middle socioeconomic status (SES) was adopted, based on the classification from the Instituto Nacional de Estudos e Pesquisas Educacionais Anísio Teixeira (INEP, 2015/2017), considering where the school is located and its indexes obtained in the Prova Brasil (2011/2013).

The goal of the syntactic awareness test (PCS) ${ }^{23}$ is to assess the metasyntactic skills of elementary school students. It is composed of four subtests, namely:

- Subtest 1 - Grammatical judgment: in this test, the schoolchild is asked to judge the grammaticality of 20 sentences - 10 grammatical and 10 ungrammatical (with morpheme errors and inverted order);

- Subtest 2 - Grammatical correction: in this test, the schoolchild is asked to correct 10 ungrammatical sentences (with morpheme errors and inverted order);

- Subtest 3-Grammatical correction of ungrammatical and nonsemantic sentences: in this test, the schoolchild is asked to correct the grammatical error of 10 sentences, without changing the semantic error;

- Subtest 4 - Word categorization: in this test, the schoolchild is asked to categorize 15 words as a noun, verb, or adjective.

The final score is obtained by calculating the schoolchild's number of right answers; the maximum score is 55 points. Based on the final score, the schoolchildren's performance was classified from "very low" to "very high", following the score established by the instrument.

The goal of the word dictation test ${ }^{24}$ is to verify the access to the phonological and lexical routes to enable coding through low- and high-frequency word writing. This test was chosen because it presents a preestablished analysis criteria to classify the selected items. The criteria are grapheme-phoneme regularity (regular or irregular), occurrence frequency (high or low), and 
lexicality to decode short and long words. The test comprises 72 psycholinguistic items, distributed as follows: 47 regular, and 25 irregular words; 36 highfrequency, and 36 low-frequency words; 40 short, and 32 long words. The analysis was based on one point given to each correctly written answer.

The writing under dictation test ${ }^{25}$ was conducted through the dictation of letters for them to form real words. This test's goal is to verify the schoolchild's ability to synthesize dictated letters to form a word, using the stored information and orthographic lexicon.

The test comprises 29 three- to nine-letter words two of them have three letters; six have four letters; ten have five letters; three have six letters; five have seven letters; two have eight letters; one has nine letters. Each correctly written answer was given one point.

The instruments were administered during the school year, in regular school hours, in four sessions averaging 20 to 30 minutes, in randomly formed groups of three to five students.

The variables were described by mean, standard deviation (SD), minimum and maximum values, as well as the distribution of the quartile represented by the measure that corresponds to the second quartile $\left(50^{\text {th }}\right)$, and by the first $\left(25^{\text {th }}\right)$ and third quartiles $\left(75^{\text {th }}\right)$.
The normality distribution was verified through the Kolmogorov-Smirnov test. The relationship between the variables was analyzed through the Spearman correlation test and through the $\mathrm{R}^{2}$ value, which represents the variation percentage of a dependent variable explained by the variation of an independent variable. The level of significance adopted was $5 \%$ ( $p \leq 0.05)$, and the data were analyzed with the SPSS software, version 19.0.

The correlation coefficient values used range from 0 to 1 , which can result in a positive or negative correlation. The values of this coefficient were interpreted as follows: 0.0 to 0.25 - nonexistent-to-low correlation; 0.25 to 0.50 - low-to-moderate correlation; 0.50 to 0.75 - moderate-to-high correlation; $\geq 0.75$ - high correlation ${ }^{26}$.

\section{RESULTS}

The results were presented in tables, indicating the statistically significant data for the analysis of variables obtained in the vocabulary, syntactic awareness, word dictation, and writing under dictation tests. The mean, standard deviation, and median obtained in the analysis of variables are presented in Table 1.

Table 1. Distribution of the results of the descriptive statistical analysis of vocabulary, syntactic awareness, word dictation, and writing under dictation, by mean, standard deviation, median, 50th (second quartile); 25th (first quartile); 75th (third quartile)

\begin{tabular}{lccccccc}
\hline & Mean & SD & Minimum & Maximum & Median & 25th & 75th \\
\hline $\begin{array}{l}\text { Vocabulary } \\
\text { Identification }\end{array}$ & 105.0 & 10.6 & 74.0 & 126.0 & 105.5 & 98.0 & 112.2 \\
\hline Syntactic awareness & & & & & & & \\
Gram Jud & 18.1 & 2.2 & 10.0 & 20.0 & 19.0 & 18.0 & 19.3 \\
Gram Cor & 8.7 & 1.6 & 4.0 & 10.0 & 9.0 & 8.0 & 10.0 \\
Gram Cor Ungr Non & 8.4 & 2.2 & 1.0 & 10.0 & 9.0 & 7.0 & 10.0 \\
Word Categ & 8.0 & 3.4 & 1.0 & 15.0 & 8.0 & 5.0 & 11.0 \\
\hline Word dictation & & & & & & & \\
HF SRW & 11.9 & 4.2 & 1.0 & 16.0 & 13.0 & 11.0 & 15.0 \\
HF LRW & 6.0 & 2.5 & 0.0 & 8.0 & 7.0 & 5.0 & 8.0 \\
HF LIW & 7.5 & 3.8 & 0.0 & 13.0 & 8.0 & 5.0 & 10.3 \\
HF LIW & 5.9 & 3.1 & 0.0 & 10.0 & 6.0 & 3.8 & 9.0 \\
LF SRW & 2.2 & 1.3 & 0.0 & 4.0 & 2.0 & 1.0 & 3.0 \\
LF LRW & 3.3 & 2.4 & 0.0 & 8.0 & 2.5 & 2.0 & 5.3 \\
LF SIW & 2.2 & 1.7 & 0.0 & 7.0 & 2.0 & 1.0 & 3.0 \\
LF LIW & 1.4 & 1.4 & 0.0 & 5.0 & 1.0 & 0.0 & 2.0 \\
\hline Writing under dictation & & & & & & & \\
Cor Writ & 12.6 & 6.7 & 1.0 & 27.0 & 12.0 & 7.8 & 16.3 \\
\hline
\end{tabular}

The Kolmogorov-Smirnov test was used for normality distribution

Captions: SD: standard deviation; Gram Jud: grammatical judgment; Gram Cor: grammatical correction; Gram Cor Ungr Non: grammatical correction of ungrammatical and nonsemantic sentences; Word Categ: word categorization; HF SRW: high-frequency short regular words; HF LRW: high-frequency long regular words; HF SIW: high-frequency short irregular words; HF LIW: high-frequency long irregular words; LF SRW: low-frequency short regular words; LF LRW: low-frequency long regular words; LF SIW: Iow-frequency short irregular words; LF LIW: low-frequency long irregular words; Cor Writ: correctly written 
The results obtained in the correlation between vocabulary and syntactic awareness, word dictation, and writing under dictation are presented in Table 2. The results show that there was significance in the correlation between vocabulary and the grammatical judgment (0.41), grammatical correction (0.40), and word categorization $(0.40)$ tests, which indicates a moderate positive correlation. Regarding the vocabulary and word dictation tests, there were significant results with moderate-to-high correlation for vocabulary and high-frequency short regular words (HF SRW/0.52), and high-frequency short irregular words (HF SIW/0.51). There was also a low-to-moderate correlation between vocabulary and high-frequency long irregular words (HF LIW/0.42), low-frequency short regular words (LF SRW/0.41), and low-frequency long regular words (LF LRW/0.39).

Table 2. Analysis of the correlation between vocabulary, syntactic awareness, word dictation, and writing under dictation

\begin{tabular}{lccc}
\hline & \multicolumn{3}{c}{ Vocabulary } \\
\cline { 2 - 4 } & $\mathbf{r}$ & $\mathbf{R}^{2}$ & $\mathbf{p}$-value \\
\hline Syntactic awareness & & & $0.007^{*}$ \\
Gram Jud & 0.41 & 0.17 & $0.009^{*}$ \\
Gram Cor & 0.40 & 0.16 & 0.177 \\
Gram Cor Ungr Non & 0.21 & 0.05 & $0.010^{*}$ \\
Word Categ & 0.40 & 0.16 & $<0.001^{*}$ \\
Word dictation & & & 0.131 \\
HF SRW & 0.52 & 0.27 & $0.001^{*}$ \\
HF LRW & 0.24 & 0.06 & $0.006^{*}$ \\
HF SIW & 0.51 & 0.26 & $0.007^{*}$ \\
HF LIW & 0.42 & 0.17 & $0.011^{*}$ \\
LF SRW & 0.41 & 0.17 & 0.053 \\
LF LRW & 0.39 & 0.15 & 0.051 \\
LF SIW & 0.30 & 0.09 & 0.105 \\
LF LIW & 0.30 & 0.09 & \\
\hline Writing under dictation & & 0.06 & \\
Cor Writ & 0.25 & & \\
\hline
\end{tabular}

* Spearman correlation coefficient test (r); R2: percentage of variation of the dependent variable (vocabulary) explained by the variation of the independent variable (syntactic awareness, word dictation, and writing under dictation);

* $p$-value $\leq 0.05$ indicates significant correlation according to Spearman Test.

Captions: Gram Jud: grammatical judgment; Gram Cor: grammatical correction; Gram Cor Ungr Non: grammatical correction of ungrammatical and nonsemantic sentences; Word Categ: word categorization; HF SRW: high-frequency short regular words; HF LRW: high-frequency long regular words; HF LIW: high-frequency long irregular words; HF LIW: high-frequency long irregular words; LF SRW: low-frequency short regular words; LF LRW: low-frequency long regular words; LF SIW: lowfrequency short irregular words; LF LIW: low-frequency long irregular words; Cor Writ: correct writing

The correlation data between syntactic awareness, word dictation, and writing under dictation are presented in Table 3 , indicating statistically significant values for grammatical judgment and word dictation, with a moderate positive correlation for high-frequency short regular words (HF SRW/0.48), high-frequency short irregular words (HF SIW/0.48), low-frequency short irregular words (LF SIW/0.46), and low-frequency long irregular words (LF LIW/0.43). There was a moderate-to-high positive correlation for high-frequency long regular words (HF LRW/0.51), high-frequency long irregular words (HF LIW/0.58), low-frequency short regular words (LF SRW/0.54), and low-frequency long regular words (LF LRW/0.54).

For grammatical correction, there was a moderate positive correlation for high-frequency short regular words (HF SRW/0.44), high-frequency long regular words (HF LRW/0.39), high-frequency short irregular words (HF SIW/0.32), high-frequency long irregular words (HF LIW/0.37), low-frequency short regular words (LF SRW/0.35), low-frequency long regular words (LF LRW/0.43), and low-frequency long irregular words (LF LIW/0.33). In the analysis of grammatical correction, and ungrammatical and nonsemantic sentences, there 
was a moderate positive correlation for high-frequency short regular words (HF SRW/0.33), low-frequency short regular words (LF SRW/0.49), and low-frequency long regular words (LF LRW/0.39).

For the analysis of grammatical categorization, there was a significance for correlation between high-frequency short regular words (HF SRW/0.41), high-frequency long regular words (HF LRW/0.35), high-frequency short irregular words (HF SIW/0.35), high-frequency long irregular words (HF LIW/0.36), high-frequency short regular words (HF SRW/0.42), and low-frequency long regular words (LF LRW/0.35), indicating a moderate positive correlation. For grammatical judgment and writing under dictation, there was a high positive correlation (0.59).
The data obtained in the correlation between word dictation and writing under dictation are presented in Table 4. Based on the results, there was a statistically significant difference between all the variables analyzed, indicating moderate-to-high positive correlation, namely: high-frequency short regular words (HF SRW/0.59), high-frequency long regular words (HF LRW/0.60), high-frequency short irregular words (HF SIW/0.51), high-frequency long irregular words (HF LIW/0.61), low-frequency short regular words (LF SRW/0.57), low-frequency long regular words (LF LRW/0.56), low-frequency short irregular words (LF SIW/0.51), and low-frequency long irregular words (LF LIW/0.61).

Table 3. Analysis of the correlation between syntactic awareness, word dictation, and writing under dictation

\begin{tabular}{|c|c|c|c|c|c|c|c|c|c|c|c|c|}
\hline & \multicolumn{12}{|c|}{ Consciência Sintática } \\
\hline & \multicolumn{3}{|c|}{ Gram Jud } & \multicolumn{3}{|c|}{ Gram Cor } & \multicolumn{3}{|c|}{ Gram Cor Ungr Non } & \multicolumn{3}{|c|}{ Word Categ } \\
\hline & $r$ & $\mathbf{R}^{2}$ & p-value & $r$ & $\mathbf{R}^{2}$ & p-value & $r$ & $\mathbf{R}^{2}$ & p-value & $r$ & $\mathbf{R}^{2}$ & p-value \\
\hline \multicolumn{13}{|l|}{$\begin{array}{l}\text { Word } \\
\text { dictation }\end{array}$} \\
\hline HF SRW & 0.48 & 0.23 & $0.001^{*}$ & 0.44 & 0.20 & $0.003^{*}$ & 0.33 & 0.11 & $0.031^{*}$ & 0.41 & 0.17 & $0.007^{*}$ \\
\hline HF LRW & 0.51 & 0.26 & $0.001^{*}$ & 0.39 & 0.15 & $0.012^{*}$ & 0.23 & 0.05 & 0.146 & 0.35 & 0.12 & $0.022^{*}$ \\
\hline HF SIW & 0.48 & 0.23 & $0.001^{*}$ & 0.32 & 0.10 & $0.041^{\star}$ & 0.24 & 0.06 & 0.126 & 0.35 & 0.12 & $0.025^{\star}$ \\
\hline HF LIW & 0.58 & 0.34 & $<0.001^{*}$ & 0.37 & 0.14 & $0.015^{\star}$ & 0.23 & 0.05 & 0.138 & 0.36 & 0.13 & $0.019^{*}$ \\
\hline LF SRW & 0.54 & 0.29 & $<0.001^{\star}$ & 0.35 & 0.12 & $0.024^{*}$ & 0.49 & 0.24 & $0.001^{*}$ & 0.42 & 0.17 & $0.006^{*}$ \\
\hline LF LRW & 0.54 & 0.29 & $<0.001^{\star}$ & 0.43 & 0.19 & $0.004^{*}$ & 0.39 & 0.15 & $0.011^{*}$ & 0.35 & 0.12 & $0.020^{*}$ \\
\hline LF SIW & 0.46 & 0.21 & $0.002^{*}$ & 0.29 & 0.09 & 0.060 & 0.23 & 0.05 & 0.146 & 0.22 & 0.05 & 0.158 \\
\hline LF LIW & 0.43 & 0.19 & $0.004^{*}$ & 0.33 & 0.11 & $0.030^{*}$ & 0.28 & 0.08 & 0.071 & 0.24 & 0.06 & 0.121 \\
\hline \multicolumn{13}{|l|}{$\begin{array}{l}\text { Writing } \\
\text { under } \\
\text { dictation }\end{array}$} \\
\hline Cor Writ & 0.59 & 0.35 & $<0.001^{\star}$ & 0.27 & 0.07 & 0.089 & 0.23 & 0.05 & 0.147 & 0.27 & 0.08 & 0.079 \\
\hline
\end{tabular}


Table 4. Analysis of the correlation between word dictation and writing under dictation

\begin{tabular}{lccc}
\hline & \multicolumn{3}{c}{ Writing under dictation } \\
\cline { 2 - 4 } & $\mathbf{r}$ & \multicolumn{3}{c}{ Correct Writing } \\
\cline { 2 - 4 } Word dictation & & $\mathbf{R}^{2}$ & p-value \\
HF SRW & 0.59 & 0.34 & $<0.001^{*}$ \\
HF LRW & 0.60 & 0.36 & $<0.001^{*}$ \\
HF SIW & 0.51 & 0.26 & $0.001^{*}$ \\
HF LIW & 0.61 & 0.38 & $<0.001^{*}$ \\
LF SRW & 0.57 & 0.32 & $<0.001^{*}$ \\
LF LRW & 0.56 & 0.31 & $<0.001^{*}$ \\
LF SIW & 0.51 & 0.26 & $0.001^{*}$ \\
LF LIW & 0.61 & 0.38 & $<0.001^{*}$ \\
\hline
\end{tabular}

* Spearman correlation coefficient test (r); R2 percentage of variation of the dependent variable (vocabulary) explained by the variation of the independent variable (syntactic awareness, word dictation, and writing under dictation);

* $p$-value $\leq 0.05$ indicates significant correlation according to Spearman Test.

Legend: Gram Jud: grammatical judgment; Gram Cor: grammatical correction; Gram Cor Ungr Non: grammatical correction of ungrammatical and nonsemantic sentences; Word Categ: word categorization; HF SRW: high-frequency short regular words; HF LRW: high-frequency long regular words; HF SIW: high-frequency short irregular words; HF LIW: high-frequency long irregular words; LF SRW: low-frequency short regular words; LF LRW: low-frequency long regular words; LF SIW: Iowfrequency short irregular words; LF LIW: low-frequency long irregular words

\section{DISCUSSION}

Approaching the correlation between analyzed variables enabled the identification of positive correlation ranging from low to high, according to the variables correlated, and the influence of a given skill on its analyzed match.

Regarding the analysis of the vocabulary and syntactic awareness tests, there was a moderate positive correlation between vocabulary and grammatical judgment, grammatical correlation, and word categorization. Such results indicate that vocabulary consolidation favorably reflects grammatical development since the broader the vocabulary acquired by the child (stimulated by their surroundings, their initial schoolyears, or their learning how to read), better will the development of the lexical memory be, reflected on the performance of grammatical skills,27.

Being introduced to the third-grade content enables the child to consciously use the morphosyntactic skills, as these schoolchildren begin to be presented to the formal learning of orthographic rules. Broadening the vocabulary is also a complementary tool to comprehension, due to the increased complexity required in reading narrative and expository texts, which gives access to using and handling vocabulary in linguistic activities $^{28}$.

For the correlation between vocabulary and the variables analyzed in the real-word dictation test, there was a moderate-to-high positive correlation for short regular and irregular words, classified as highfrequency ones. This suggests that, the more the child is exposed to words, the better is the development of sequential memory and the access to the lexicon, as it occurs more efficiently, especially in the case of short words $^{29}$.

In the case of high-frequency long irregular words regardless of the time the child is exposed to the word - these are more likely to have a greater number of orthographic rules applied to them, due to its complex structure. This can also be observed in low-frequency short and long irregular words because they are not registered in the lexical memory; they are accessed through the phonological memory route, which justifies the low-to-moderate correlation ${ }^{5,30}$.

The performance analysis between writing under dictation and the variables belonging to the real-word dictation test points to a moderate-to-high positive correlation. The correlation between these tests suggests the child's need, when coding, to use the sequential memory associated with the phonological and lexical routes of access to information, based on auditory discrimination, and alphabet letters identification and handling, to form words ${ }^{31}$.

Given the results obtained in this study, as well as in national and international research ${ }^{3,12,13,29,32}$, it is understood that the greater the schoolchild's ability to discriminate, store, and retrieve auditory information, the better are their real-word writing performance, 
regardless of being high- or low-frequency, regular or irregular, short or long words ${ }^{33}$.

In the analysis of the syntactic awareness and word dictation tests, there was a positive correlation for all tests analyzed. These were identified as moderate for high-frequency short regular and irregular words and low-frequency long and short irregular words. Moreover, there was a moderate-to-high correlation for high-frequency regular and irregular words and low-frequency short and long regular words. These results indicate that the influence of knowing Portuguese language orthographic rules is directly related to the access to grammatical information for the coding of regular - and especially irregular - words ${ }^{20,34}$.

The influence of lexical memory is intensified mainly in the sequencing of high-frequency short words when correlated with the low-frequency irregular words, with the interference of the orthographic transparency and opacity factors. This is so because the words with transparent orthographic representation are more easily written and identified in the orthographic aspects - differently from words with irregularities, which require a deeper knowledge of writing norms $\mathrm{s}^{35,36}$.

Such reflex can be identified in the moderate-to-high positive correlation between grammatical judgment and writing under dictation, because the sequential memory, both for single sequences and longer structures (syllables and words), depends on the rules and representativity in the lexical memory, suggesting that the greater the capacity to retain word structure in the writing under dictation, better is the capacity to analyze and synthesize the segments ${ }^{37,38}$.

For the analysis of the correlation between the syntactic awareness skill and word dictation tests, there was a moderate positive correlation for grammatical correction, grammatical correction of ungrammatical and nonsemantic sentences, and grammatical categorization. The data suggest that the correlation between the tests associated with syntactic awareness both influences and is interfered with by the knowledge of words because, for the child to be able to make grammatical corrections in the sentences, they must understand the rules of the Portuguese language. Knowing the rules enables the child to correct wrong sentences, identifying which segment or segments are incorrect. Hence, they join metacognitive skills when they hear a sentence and identify whether what they heard makes sense or not ${ }^{20,39}$.

These notes can be identified in the grammatical categorization test as well, since the child, in addition to using metacognitive aspects, needs to identify the word that is being read, placing it in specific categories. Thus, the child must know the function of a given word regardless of its context because understanding the word's meaning can decisively interfere in its classification. In this sense, the frequency and extension of the words used in classification also associate with each child's knowledge, which can be a positive factor for correlation ${ }^{40}$.

The data obtained in this study is a preliminary result achieved in a sample that is to be broadened. To this end, the study can be continued by extending the sample to include fourth and fifth graders, thus furnishing more in-depth analysis and greater reliability of the data obtained.

\section{CONCLUSION}

This study's results lead to the conclusion that there was a moderate-to-high positive correlation between all the variables analyzed, except for vocabulary and word dictation with low-frequency words and highfrequency irregular ones. This indicates that the acquisition and comprehension of vocabulary enable the child to handle grammatical structures associated with syntactic awareness, as well as those necessary to code words in dictation.

\section{REFERENCES}

1. Amorim WW, Sampaio NFS, Temponi CN, Zamilute IAG, Cavalcante DC, Ikuta VV. Neurofisiologia da escrita: o que acontece no cérebro humano quando escrevemos? Rev. Neuropsicol. Lat.am. 2016;8(10):1-11.

2. Correa KCP, Machado MAMP, Hage SRV. Skills for the literacy process. CoDAS. 2018;30(1):e20170039.

3. Carretti B, Motta E, Re AM. Oral and written expression in children with reading comprehension difficulties. J Learn Disabil. 2016;49(1):65-76.

4. Schirmer CR, Fontoura DR, Nunes ML. Language and learning disorders. J Pediatr. 2004;80(2):95-103.

5. Caravolas M. Growth of word and pseudoword reading efficiency in alphabetic orthographies: impact of consistency. J Learn Disabil. 2018;51(5):422-33.

6. Fernández AY, Mérida JC, Cunha VLO, Batista AO, Capellini SA. Avaliação e intervenção da disortografia baseada na semiologia dos 
erros: revisão da literatura. Rev. CEFAC. 2010;12(3):499-504.

7. Dias NM, Bueno JOS, Pontes JMM, Tatiana P. Linguagem oral e escrita na Educação Infantil: relação com variáveis ambientais. Psicol. Esc. Educ. 2019;23:e178467.

8. Erbeli F, Hart SA, Taylor J. Genetic and environmental influences on achievement outcomes based on family history of learning disabilities status. J Learn Disabil. 2019;52(2):135-45.

9. Sargiani RA, Maluf MR. Linguagem, cognição e educação infantil: contribuições da psicologia cognitiva e das neurociências. Psicol. Esc. Educ. 2018;22(3):477-84.

10. Ferracini F, Capovilla AGS, Dias NM, Capovilla FC. Avaliação de vocabulário expressivo e receptivo na educação infantil. Rev Psicopedagogia. 2006;23(71):124-33.

11. Correa J. A avaliação da consciência sintática na criança: uma análise metodológica. Psic.: Teor. e Pesq. 2004;20(1):69-75.

12. Capovilla AGS, Capovilla FCS, Soares JVT. Consciência sintática no ensino fundamental: correlações com consciência fonológica, vocabulário, leitura e escrita. Psico-USF. 2004;9(1):39-47.

13. Rebello BM, Santos GL, Ávila CRB, Kida ASB. Effects of syntactic simplification on reading comprehension of elementary school children. Audiol Commun Res. 2019;24:e1985.

14. Cardoso MH, Romero ACL, Capellini SA. Alterações de processos fonológicos e índice de gravidade em uma amostra de fala e de escrita de escolares de ensino público e privado. Rev. Psicopedagogia. 2016;33(102):283-93.

15. Teixeira BS, Schiefer AM, Carvalho CAF, Àvila CRB. Listening and reading comprehension and syntactic awareness in reading and writing disorders. Rev. CEFAC. 2016;18(6):1370-8.

16. Uvo MFC, Germano GD, Capellini SA. Performance of students with attention deficit hyperactivity disorder in metalinguistic skills, reading and reading comprehension. Rev. CEFAC. 2017;19(1):7-19.

17. Pestun MSV, Omote LCF, Barreto DCM, Matsuo T. Estimulação da consciência fonológica na educação infantil: prevenção de dificuldades na escrita. Psicol. Esc. Educ. 2010;14(1):95-104.

18. Rosa CC, Gomes E, Pedroso FS. Aquisição do sistema ortográfico: desempenho na expressão escrita e classificação dos erros ortográficos. Rev. CEFAC. 2011;14(1):39-45.

19. Vale AP, Sousa O. Conhecimento ortográfico e escrita. Invest Práticas. 2017;7(3):3-8.

20. Tighes LE, Schatschneider CA. Quantile regression approach to understanding the relations among morphological awareness, vocabulary, and reading comprehension in adult basic education students. J Learn Disabil. 2016;49(4):424-36.

21. Ives DC, Casella EB, Ferraro AA. Spelling performance of students with developmental dyslexia and with developmental dyslexia associated to attention deficit disorder and hyperactivity. CoDAS. 2016;28(2):123-31.

22. Capovilla FC. Teste de vocabulário por figuras USPTVfusp. São Paulo: Memnon. Edições Científicas, 2011.

23. Capovilla AGS, Capovilla CF. Prova de Consciência Sintática - PCS. São Paulo: Memnon, 2006.

24. Pinheiro AMV. Avaliação cognitiva das capacidades de leitura e de escrita de crianças nas séries iniciais do ensino fundamental - AVACLE: Relatório Final Global e Integrado de atividades desenvolvidas, submetido ao Conselho Nacional de Desenvolvimento Científico e Tecnológico (Processo 52089/93-0). Belo Horizonte, MG: Universidade Federal de Minas Gerais, Departamento de Psicologia, 2003.

25. Batista AO, Cervera-Mérida JF, Ygual-Fernández A, Capellini SA. Pró-Ortografia Protocolo de Avaliação da Ortografia para Escolares do $2^{\circ}$ ao $5^{\circ}$ ano do ensino fundamental. Carapicuiba: Editora Pró-fono, 2014.

26. Dawson B, Trapp RG. Bioestatística básica e clínica. 3 ed. Rio de Janeiro: McGraw-Hill, 2001.

27. Castro DAS, Barrera SD. The contribution of emergent literacy skills for early reading and writing achievement. Trends Psychol. 2019;27(2):509-22.

28. Potocki A, Sanchez M, Ecalle J, Magnan A. Linguistic and cognitive profiles of 8- to 15-year-old children with specific reading comprehension difficulties: the role of executive functions. J Learn Disabil. 2017;50(2):128-42.

29. Batista AO, Capellini SA. Desempenho ortográfico de escolares do 2 ㅇ ao 5 o ano do ensino privado do município de Londrina. Psicol Argum. 2011;29(67):411-25.

30. Oliveira AM, Germano GD, Capellini SA. Students' performance in letter identification and lexical process tests. Rev. CEFAC. 2016;18(5):1121-32. 
31. Pinheiro AMV, Rothe-Neves R. Avaliação cognitiva de leitura e escrita: as tarefas de leitura em voz alta e ditado. Psicol Refl Crít. 2001;14(2):399-408.

32. Sampaio MN. Spelling performance of elementary school students: developing and implementing an instrument of intervention. Rev. Soc. Bras. Fonoaudiol. 2012;17(4):509.

33. Cárnio MS, Sá BCM, Jacinto LA, Soares AJC. Phonological short-term memory and phonological awareness in students from the Elementary School. CoDAS. 2015;27(5):458-63.

34. Paolucci JF, de Ávila CRB. Competência ortográfica e metafonológica: influências e correlações na leitura e escrita de escolares da 4a a série. Rev Soc Bras Fonoaudiol. 2009;14(1):48-55.

35. Zorzi JL, Ciasca SM. Análise de erros ortográficos em diferentes problemas de aprendizagem. Rev. CEFAC. 2009;11(3):406-16.

36. Donicht G, Ceron MI, Keske-Soares M. Spelling errors and phonological awareness skills in children with typical and atypical phonological development. CoDAS. 2019;31(1):e20170212.

37. Rego LLB. O papel da consciência sintática na aquisição da língua escrita. Temas Psicol. 1993;1(1):79-87.

38. Schiff R, Ben-Shushan YN, Ben-Artzi E. Metacognitive strategies: a foundation for early word spelling and reading in kindergartners with SLI. J Learn Disabil. 2017;50(2):143-57.

39. Seabra AG, Dias NM. Reconhecimento de palavras e compreensão de leitura: dissociação e habilidades linguístico-mnemônicas preditoras. Rev. Neuropsicol. Lat.am. 2012;4(1):43-56.

40. Gaiolas MS, Martins MA. Conhecimento metalinguístico e aprendizagem da leitura e da escrita. Análise Psicol. 2017;35(2):117-24. 